\title{
Quantitative RT-PCR to Evaluate In Vivo Expression of Multiple Transgenes Using a Common Intron
}

BioTechniques 27:566-574 (September 1999)

J. Fairman, L. Roche, I. Pies-
lak, M. Lay, S. Corson, E. Fox,
C. Luong, G. Koe, B. Lemos,
R. Grove, L. Fradkin and J.
Vernachio
Valentis, Burlingame, CA, USA

\begin{abstract}
An assay measuring RNA expression levels of a gene-encoded therapeutic must distinguish between endogenous $m R N A$ and mRNA transcribed from the transgene. Specificity for the delivered transgene is especially critical when the treatment involves genes that are expressed in the target tissue. To facilitate uniform detection of transgene RNA without interference from endogenous $m R N A$, we have engineered expression vectors that include a $5^{\prime}$ untranslated region (5' UTR) containing a synthetic intron (PGL3). The synthetic intron splice junction was the target sequence for a quantitative reverse transcription ( $R T)$-PCR assay utilizing TaqMan ${ }^{\circledR}$ technology. In this study, we demonstrate that a quantitative RT-PCR assay designed to recognize an engineered intron splice site in the 5'UTR of expression constructs effectively measures the expression level of in vivo-delivered gene therapeutics.
\end{abstract}

\section{INTRODUCTION}

Many techniques have been developed for the quantitative analysis of DNA and RNA $(7,9,10)$. However, most of these techniques lack the sensitivity and reproducibility for routine analysis. These procedures also require considerable time, sample size and extensive manipulation of the samples, increasing the possibility of contamination or degradation of the sample. Reverse transcription polymerase chain reaction (RT-PCR) has proven to be a powerful tool for quantitative RNA analysis $(1,6)$, even in the case of very low copy number messages in a considerable background of endogenous RNA.

The TaqMan ${ }^{\circledR}$ methodology offers a high-throughput, sensitive and accurate PCR-based assay system that is useful for monitoring in vivo therapeutic gene delivery and expression. The system is based on the $5^{\prime}$ exonuclease activity of the Taq DNA polymerase for detection of PCR products $(3,4)$. The detection is accomplished by using a nonextendable oligonucleotide probe that hybridizes to the sequence undergoing amplification. The probe is labeled with a reporter dye [FAM (6-carboxyfluorescein)] at the $5^{\prime}$ end and a quencher dye [TAMRA (6-carboxytetramethyl-rhodamine)] at the $3^{\prime}$ end. When the probe is intact, fluorescent resonance energy transfer to TAMRA quenches the FAM emission. During the extension phase of PCR, the $5^{\prime}$ nuclease activity of the Taq DNA polymerase cleaves the hybridization probe at the $5^{\prime}$ end and releases the reporter dye. The resulting relative increase in fluorescence emission of reporter vs. quencher is monitored in real time during the PCR amplification. The PCR cycle at which the fluorescence attains a point above a user-determined threshold is defined as the threshold cycle $\left(C_{t}\right)$. The $C_{t}$ is inversely proportional to the log of the starting copy number in the PCR (4).

A major limitation in the analysis of RNA expression of transfected genes is the recognition of endogenous mRNA identical to the transgene target sequence. Traditionally, recognition of endogenous RNA is overcome by designing amplification primers such that one primer recognizes the vector backbone while the other is gene specific (5). Although this strategy allows for transgene specificity, a distinct primer set needs to be designed and tested for each gene of interest. We have devised a quantitative (q)RT-PCR method that allows us to monitor the expression of any transgene within a common expression vector without interference from endogenous sources. In the assay scheme, the PCR product is contained entirely within the $5^{\prime}$ untranslated region $\left(5^{\prime}\right.$ UTR) portion of the expression construct. Targeting the non-coding portion of the mRNA eliminates false signals due to endogenous RNA, while allowing universal recognition of any promoter/transgene combination cloned into the expression vector. In this study, we describe the development of this quantitative RT-PCR assay, illustrate its use in measuring transgene expression levels after systemic plasmid delivery in mice and compare this method vs. traditional methods of monitoring transgene 
expression. We believe this method will be widely applicable for monitoring viral or nonviral therapeutic gene expression vectors in vivo.

\section{MATERIALS AND METHODS}

\section{Formulation}

For lipid DNA formulation MB134, the plasmid DNA was prepared in a 10 $\mathrm{mM}$ solution of Tris- $\mathrm{HCl}, \mathrm{pH} 7.0$ (Sigma), (2-amino-2-hydroxymethyl-1,3propanediol hydrochloride), $\mathrm{pH} 8.0$ at $5.0 \mathrm{mg} / \mathrm{mL}$. Liposomes were prepared by dissolving cholesterol (Sigma, St. Louis, MO, USA) and the cationic lipid, MBN275 (Valentis, Burlingame, CA, USA) in chloroform (EM Science, Gibbstown, NJ, USA) at equimolar concentrations in a 3 -L round bottom flask. The clear solution was rotated on a Rotovapor R-134 (Büchi, Zurich, Switzerland) at $30^{\circ} \mathrm{C}$ for $30 \mathrm{~min}$ and hydrated in $5 \% \mathrm{wt} / \mathrm{vol}$ dextrose (McGraw, Irvine, CA, USA) to produce a nominal concentration of $40 \mathrm{mM}$. The liposome dispersion was extruded through successive filters $(0.4,0.2,0.1$ and $0.05 \mu \mathrm{m})$ to obtain a vesicle size of approximately 100 $\mathrm{nm}$ as measured by a Nicomp C-370 Particle Sizer (Particle Sizing Systems, Santa Barbara, CA, USA). The stock DNA solution was diluted to 0.625 $\mathrm{mg} / \mathrm{mL}$ with $5 \%$ wt/vol dextrose (D5W). DNA/liposome complexes were prepared by the addition of the DNA solution to an equivalent volume of liposomes at a total liposome concentration of $7.5 \mathrm{mM}$. For lipid/ DNA formulation MB127, the final DNA liposome complexes consist of a 1:6 ratio of DNA to cationic lipid (mg DNA to $\mu \mathrm{mol}$ cationic lipid) and a DNA concentration of 312.5 $\mu \mathrm{g} / \mathrm{mL}$ DNA and lipid concentrations of 1.875 mM MBN275/1.875 mM cholesterol. Lipid/DNA formulation MB112 (DOTIM/cholesterol) was prepared as reported previously (8).

\section{Expression Vectors for e-NOS, G-CSF and VEGF}

The expression plasmid contains the cDNA for the gene of interest, the cytomegalovirus (CMV) promoter/enhancer region, the simian virus 40 (SV40) early poly(A) site, the cDNA for the kanamycin resistance gene and the 5'UTR and PGL3 intron sequences.

\section{Total RNA Isolation}

Unless otherwise noted, reagents for this protocol are from the FastRNA ${ }^{\mathrm{TM}}$ Kit (Bio 101, Vista, CA, USA). Initial RNA pellets were obtained as directed by the manufacturer (Bio 101). The total RNA pellets were dissolved in 50 $\mu \mathrm{L}$ diethyl pyrocarbonate (DEPC)treated $50 \mathrm{mM}$ Tris- $\mathrm{HCl}, \mathrm{pH} 7.0,10$ $\mathrm{mM} \mathrm{MgCl}_{2}$ with $10 \mathrm{U}$ RNAse free DNAse (Roche Molecular Biochemicals, Indianapolis, IN, USA). Samples were incubated for $1 \mathrm{~h}$ at $37^{\circ} \mathrm{C}$. After incubation, $450 \mu \mathrm{L}$ of CRSR green was added and extracted with $500 \mu \mathrm{L}$ of chloroform. After centrifugation, the aqueous phase was removed, and 500 $\mu \mathrm{L}$ of isopropanol were added. The solution was mixed briefly and centrifuged at $18000 \times g$ for $5 \mathrm{~min}$ to precipitate RNA. The resulting pellet was washed with $500 \mu \mathrm{L}$ of $70 \%$ ethanol and air-dried for 5-10 min. Samples of total RNA were resuspended in $50 \mu \mathrm{L}$ TE (10 mM Tris-HCl, pH 8.0, 1 mM EDTA, 0.001\% DEPC).

\section{Preparation of RNA Standard}

The standard was prepared from a plasmid (pGEM-3Z; Promega, Madison, WI, USA) containing the PCR product of the analyte. A synthetic RNA transcript was prepared by in vitro transcription using either T7 or SP6 polymerase depending upon the orientation of the PCR product in the vector. Transcription was performed as described in the protocol supplied with the Riboprobe ${ }^{\circledR}$ in vitro Transcription Systems (Promega). Steps included linearization of the plasmid with a restriction enzyme downstream of the polymerase binding site and the cloned PCR product, purification of the DNA template by phenol:chloroform extraction, a large-scale transcription reaction using supplied components and removal of DNA template by addition of supplied DNase, followed by a phenol:chloroform extraction. Unincorporated nucleotides were removed by resin capture as described in the QIAGEN $^{\circledR}$ Nucleotide Removal Kit (Qiagen, Valencia, CA, USA) using 
DEPC-distilled (d) $\mathrm{H}_{2} \mathrm{O}$ for elution. The concentration in micrograms per milliliter of the purified, synthetic RNA standard was determined by the Ribogreen ${ }^{\circledR}$ RNA Quantitation Kit (Molecular Probes, Eugene, OR, USA) and converted to copy number/ $\mu \mathrm{L}$ by using a conversion factor based on the molecular base composition of the transcript.

\section{5'UTR Assay}

Expression of the gene of interest was monitored by RT-PCR using the ABI PRISM ${ }^{\circledR} 7700$ Sequence Detection System (PE Biosystems, Foster City, CA, USA). Amplification of all test samples was compared to amplification of an absolute standard curve of known copy number. The RNA copy number standard was diluted 1:10 in RNAse-free TE from a stock solution of $1 \times 10^{5}$ copies $/ \mu \mathrm{L}$. Aliquots of $5 \mu \mathrm{L}$ of each dilution yielded duplicate PCR standards with $5 \times 10^{5}, 5 \times 10^{4}, 5 \times 10^{3}, 5 \times 10^{2}$ and $5 \times 10^{1}$ copies of mRNA. All RTPCRs were performed with an initial RT step at $48^{\circ} \mathrm{C}$ for $30 \mathrm{~min}$ followed by an initial denaturation step of $95^{\circ} \mathrm{C}$ for 10 min. PCR was performed for 40 cycles of $\left(95^{\circ} \mathrm{C}\right.$ for $15 \mathrm{~s}$ and $60^{\circ} \mathrm{C}$ for $1 \mathrm{~min} 30$ s). Components for the RT-PCR are as follows: $8 \%$ glycerol (Sigma), 1× TaqMan Buffer (PE Biosystems), $5.5 \mathrm{mM}$ $\mathrm{MgCl}_{2}, 300 \mu \mathrm{M}$ dATP, $300 \mu \mathrm{M}$ dCTP, $300 \mu \mathrm{M}$ dGTP, $300 \mu \mathrm{M}$ dTTP, $1.25 \mathrm{U}$ AmpliTaq Gold ${ }^{\mathrm{TM}}$ DNA Polymerase (PE Biosystems), 12.5 U MuLV (Life Technologies, Gaithersburg, MD, USA), 20 U RNAse inhibitor (PE Biosystems), 150 nM PGL3 forward-1 5'-GCTACAGAAGTTGGTCGTGA-3', 150 nM PGL3 reverse-1 5'-GCGGCTGCTTAAGAGCTGTA-3' (Operon Technologies, Alameda, CA, USA), $200 \mathrm{nM}$ 5'UTR probe 6FAM-5'-TGGGCAGGTGTCCACTCCCAGGTT-3'-TAMRA (PE Biosystems).

\section{Actin Assay}

Expression of murine actin was monitored by RT-PCR using the ABI PRISM 7700 Sequence Detection System. Amplification of all test samples were compared to the amplification of an absolute standard curve of known copy number. The actin RNA copy number standard,
RT-PCRs and components were as previously described except for: $150 \mathrm{nM}$ mouse actin forward-2 5'-AGGTCATCACTATTGGCAACGA-3', $150 \mathrm{nM}$ mouse actin reverse-2 5'-CACTTCATGATGGAATTGAATGTAGTT-3' (Operon Technologies), $200 \mathrm{nM}$ actin probe 6FAM-5'-TGCCACAGGATTCCATACCCAAGAAGG-3'-TAMRA (PE Biosystems).

\section{Animal Dosing Regimen}

Mice (ICR; CD-1) were injected intravenously via the tail vein with 200 $\mu \mathrm{L}$ of lipid DNA formulations MB134, MB127 or MB112 with the expression vectors for e-NOS, G-CSF and VEGF, respectively. Lungs were harvested at the indicated time post-injection, and total RNA was prepared. Samples were analyzed in the 5'UTR and actin assay.

\section{Northern Blot}

Messenger RNA was prepared as directed by manufacturer (Cat. No. 200347-1; Stratagene, La Jolla, CA, USA). Equivalent amounts of mRNA (1

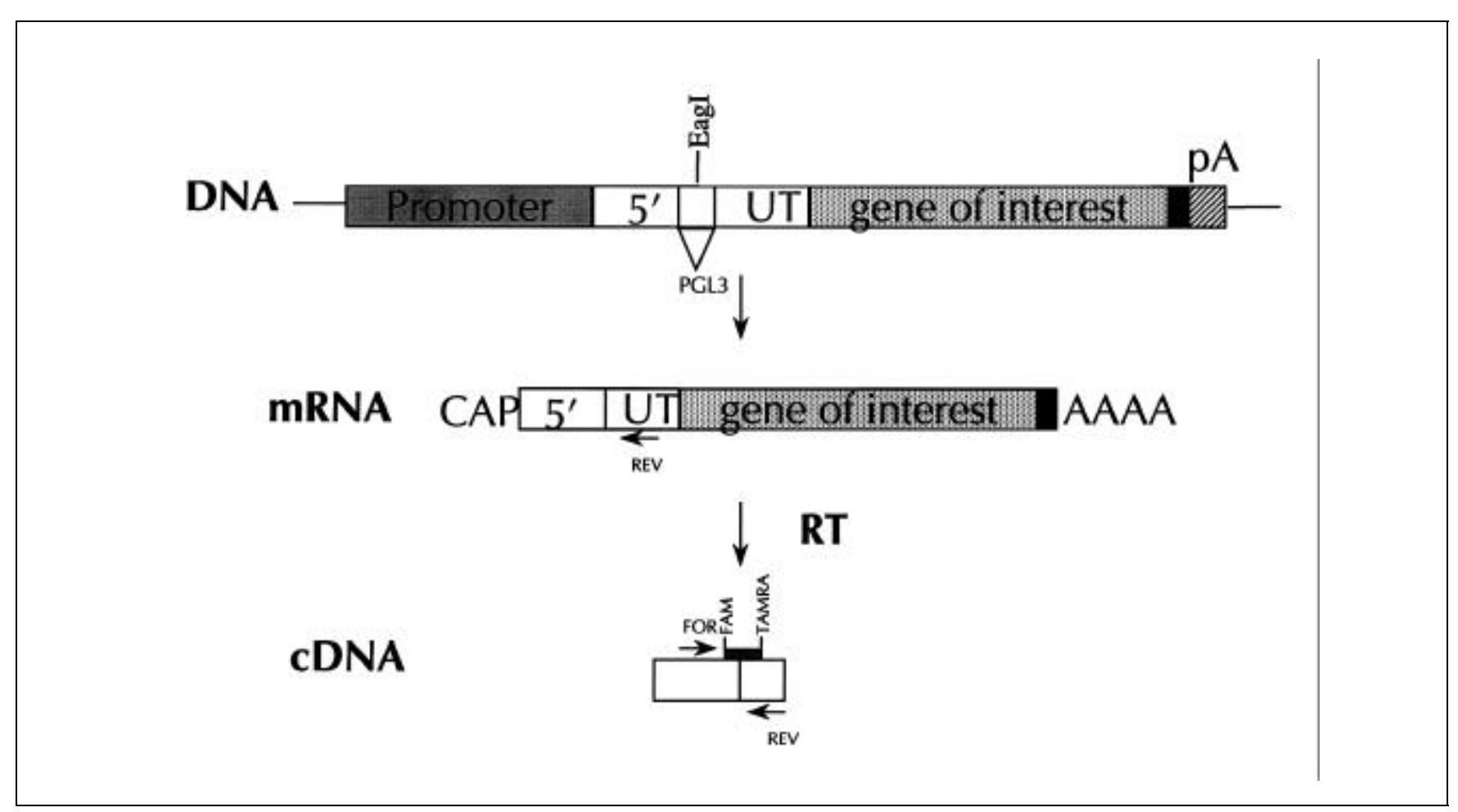

Figure 1.5'UTR amplification scheme. Plasmid is transcribed into processed mRNA. A reverse transcriptase reaction produces a cDNA of the 5'UTR region. During the process of PCR, the FAM is cleaved from the probe by the $5^{\prime}$ exonuclease activity of the Taq DNA polymerase. The probe spans the intron splice sites, with 7 bp on the $5^{\prime}$ side and $15 \mathrm{bp}$ on the $3^{\prime}$ side. 
Table 1. Test for Cross-Reactivity of Plasmid DNA

\begin{tabular}{|c|c|c|c|c|c|c|c|}
\hline \multirow{3}{*}{$\begin{array}{l}\text { Increase in } \\
\text { Signal }\end{array}$} & \multicolumn{7}{|c|}{ Plasmid Copy No. Spiked into $5 \times 10^{2}$ Copies RNA Standard } \\
\hline & $5 \times 10^{8}$ & $5 \times 10^{7}$ & $5 \times 10^{6}$ & $5 \times 10^{5}$ & $5 \times 10^{4}$ & $5 \times 10^{3}$ & $5 \times 10^{2}$ \\
\hline & 100000 & 10000 & 10000 & 60 & 10 & 2 & 1 \\
\hline
\end{tabular}

$\mu \mathrm{g})$ were loaded in each lane of an agarose gel. Transfer and northern blot were performed as directed by manufacturer of the northern blot kit (Cat. No. 1940; Ambion, Austin, TX, USA).

\section{RESULTS}

\section{Assay Design}

The primers were designed to flank the PGL-3 intron/exon splice junction. The probe spans this junction, with 9 bp on the $5^{\prime}$ side of the splice site and 15 bp $3^{\prime}$ of the intron/exon splice junction (Figure 1). The expression of the transgene was normalized against the expression of murine actin. Expression levels of the transgene and murine actin are determined by comparison with an absolute standard curve. The expression levels of the gene of interest in a given sample are then normalized to the amount of actin mRNA and are reported as the number of target mRNA copies per 1000 copies of actin mRNA.

The size of the target sequence necessitates the use of probe discrimination instead of primer discrimination. Placing the primer over the splice site would yield a product of approximately $65 \mathrm{bp}$, which is significantly below the recommended product size for this type of assay.

\section{Specificity of the Assay}

A source of concern is the detection of the plasmid DNA used to transfect the cells in vivo. This is a possible source of false positives in the assay because expression constructs are delivorgans. The signal from plasmid DNA should be minimized in the RT-PCR by ered in high copy number to selected

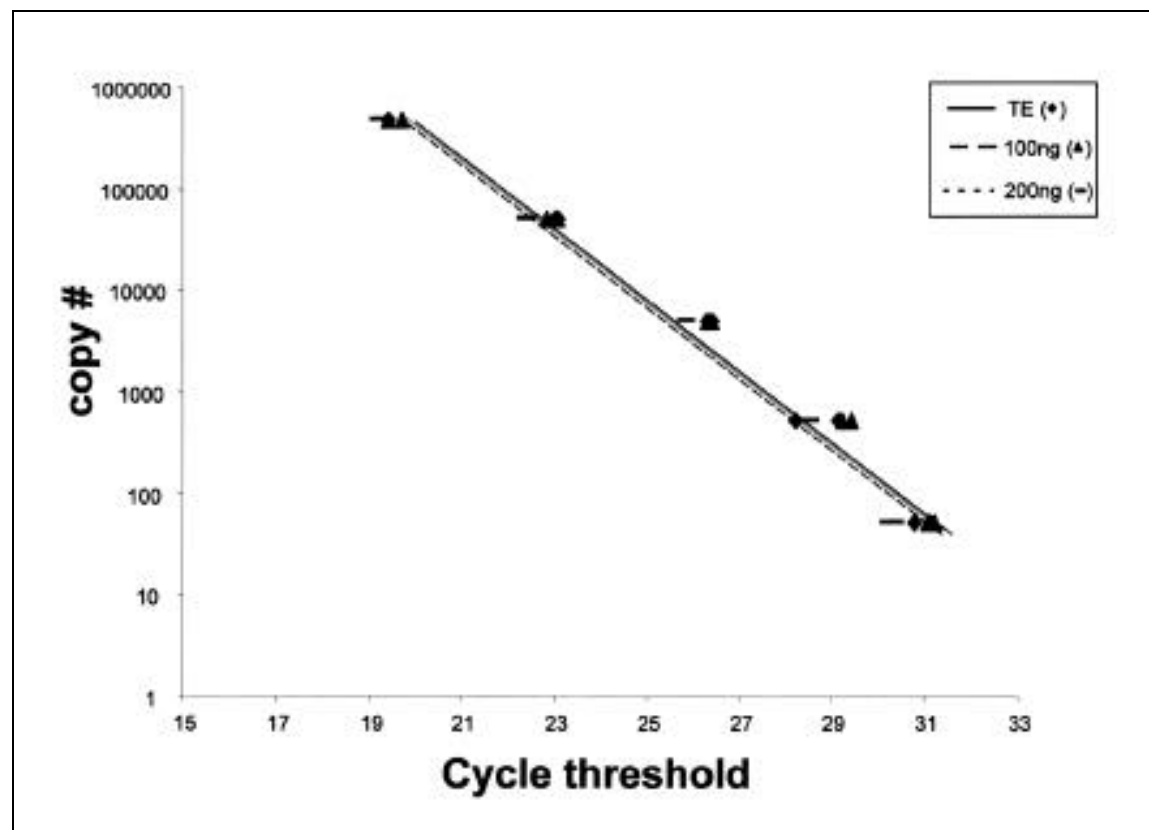

Figure 2. To determine the accuracy of the 5'UTR assay, known quantities of 5'UTR template were spiked into 100 and $200 \mathrm{ng}$ of total RNA prepared from control mouse lung tissue. The number of copies was then measured by qRT-PCR.

Table 2. Test of Treatments to Reduce Nonspecific Signal Due to High Concentrations of Plasmid DNA

\begin{tabular}{|lr|}
\hline Treatment & Increase in Signal \\
\hline No Treatment & 120000 \\
Eagl & 120000 \\
$64^{\circ} \mathrm{C}$ & 40000 \\
DNAse & 0 \\
\hline
\end{tabular}

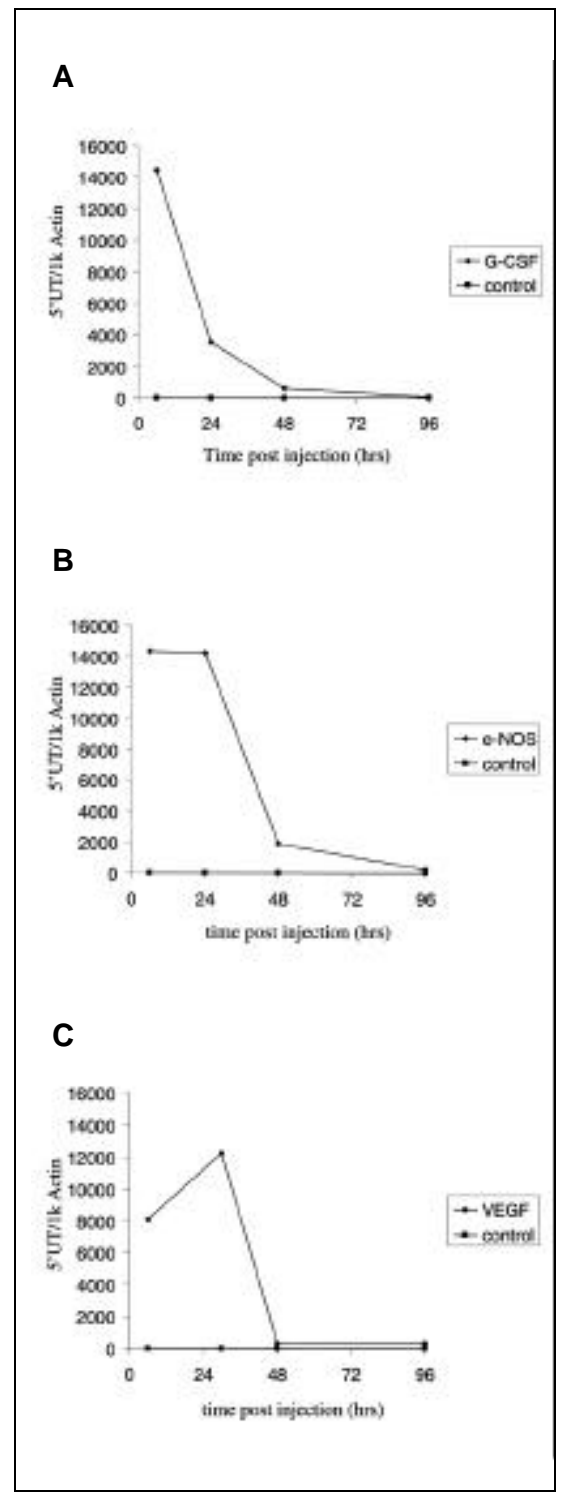

Figure 3. Transgene expression in lung after intravenous administration of a lipid/DNA complex. Control animals were injected with a similar amount of 5\% dextrose. (A) Time course of expression of G-CSF after dosing with $100 \mu \mathrm{g}$ DNA. (B) Time course of expression of e-NOS after dosing with $92 \mu \mathrm{g}$ DNA. (C) Time course of expression of VEGF after dosing with $94 \mu \mathrm{g}$ DNA. 
Table 3. 5'UTR Assay Variability

\begin{tabular}{|lrrcrr|}
\hline $\begin{array}{l}\text { Copies } \\
\text { of RNA }\end{array}$ & $\begin{array}{c}\text { Mean } \\
\text { Copy No. }\end{array}$ & $\begin{array}{c}\text { Standard } \\
\text { Deviation }\end{array}$ & $\begin{array}{c}\text { Coefficient } \\
\text { of Variance }\end{array}$ & $\begin{array}{c}\text { Median } \\
\text { Copy No. }\end{array}$ & MADa \\
\hline $5 e 5$ & 520000 & 96000 & 0.19 & 510000 & 56000 \\
$5 \mathrm{e} 4$ & 52000 & 9600 & 0.18 & 51000 & 6200 \\
$5 \mathrm{e} 3$ & 5000 & 1500 & 0.30 & 4700 & 860 \\
$5 \mathrm{e} 2$ & 500 & 200 & 0.39 & 460 & 120 \\
$5 \mathrm{e} 1$ & 63 & 26 & 0.42 & 58 & 16 \\
$(\mathrm{n}=488)$ & & & & & \\
amedian absolute deviation & & & & \\
\hline
\end{tabular}

Table 4. Actin Assay Variability

\begin{tabular}{|lrrcrr|}
\hline $\begin{array}{l}\text { Copies } \\
\text { of RNA }\end{array}$ & $\begin{array}{l}\text { Mean } \\
\text { Copy No. }\end{array}$ & $\begin{array}{l}\text { Standard } \\
\text { Deviation }\end{array}$ & $\begin{array}{l}\text { Coefficient } \\
\text { of Variance }\end{array}$ & $\begin{array}{l}\text { Median } \\
\text { Copy No. }\end{array}$ & MADa \\
\hline $5 \mathrm{e} 5$ & 480000 & 81000 & 0.17 & 480000 & 40000 \\
$5 \mathrm{e} 4$ & 54000 & 11000 & 0.20 & 54000 & 6700 \\
$5 \mathrm{e} 3$ & 5300 & 1100 & 0.20 & 5200 & 670 \\
$5 \mathrm{e} 2$ & 520 & 120 & 0.24 & 510 & 80 \\
$5 \mathrm{e} 1$ & 48 & 16 & 0.32 & 47 & 8 \\
$(\mathrm{n}=276)$ & & & & & \\
amedian absolute deviation & & & & \\
\hline
\end{tabular}

the targeting of a sequence that spans an intron splice junction (Figure 1). To test this assumption, $5 \times 10^{2}$ to $5 \times 10^{8}$ copies of plasmid DNA were spiked into $5 \times 10^{2}$ copies of sequence-specific RNA. The magnitude increase in signal was from $0-1 \times 10^{5}$ (Table 1). The increase in signal due to the plasmid DNA was unexpected, given the assay design presented in Figure 1.

Subsequently, we examined techniques to remove contaminating DNA from the total RNA samples. We investigated three different methods to achieve this: (i) digestion with EagI, (ii) increasing the annealing temperature from $60^{\circ}$ to $64^{\circ} \mathrm{C}$, and (iii) digestion with DNAse. Table 2 shows the result of using each of these three strategies. Digestion with EagI restriction enzyme did not decrease the plasmid-dependent background. Increasing the annealing temperature to $64^{\circ} \mathrm{C}$ decreased the nonspecific signal by more than $50 \%$. Treatment of the sample with DNAse eliminated the nonspecific signal.

With these findings, we chose to treat our samples with DNAse I to eliminate false positives due to DNA contamina- tion. As an added precaution, every sample is tested in a reaction that omits reverse transcriptase to confirm the complete degradation of any contaminating plasmid DNA. The presence of a reverse transcriptase signal will allow us to identify any contamination problem.

\section{Accuracy of the Assay}

To evaluate the possibility of decreased efficiency of the PCR in a more complex RNA sample, total RNA samples were spiked with known amounts of target RNA. As shown in Figure 2, the assay values correlated with the known amount of target RNA. The results indicate that in the presence of nonspecific RNA (up to $200 \mathrm{ng}$ ), the matrix had no effect on the quantitative range of the assay, and that the assay was accurate.

\section{Precision and Reproducibility of the Assay}

The precision of the $5^{\prime} \mathrm{UTR}$ and actin assays were assessed with multiple standard curves. Over 244 replicate standard curves for the 5'UTR assay
Table 5. Expression Levels of G-CSF mRMA by qRT-PCR in Samples Analyzed by Northern Hybridization (Figure 4)

\begin{tabular}{|c|c|}
\hline $\begin{array}{c}\text { Hours } \\
\text { Post-Injection }\end{array}$ & 5'UT/1 k Actin \\
\hline 6 & 560 \\
\hline 6 & 600 \\
\hline 6 & 430 \\
\hline 6 & 1000 \\
\hline 6 & 1200 \\
\hline 6 & 820 \\
\hline 12 & 2000 \\
\hline 12 & 1300 \\
\hline 12 & 1100 \\
\hline 12 & 1500 \\
\hline 12 & 1300 \\
\hline 12 & 910 \\
\hline 24 & 350 \\
\hline 24 & 1000 \\
\hline 24 & 570 \\
\hline 24 & 950 \\
\hline 24 & 580 \\
\hline 24 & 950 \\
\hline 48 & 2.5 \\
\hline 48 & 13 \\
\hline 48 & 13 \\
\hline 48 & 10 \\
\hline 48 & 6 \\
\hline 48 & 4.2 \\
\hline D5W & 0 \\
\hline D5W & 0 \\
\hline D5W & 0 \\
\hline
\end{tabular}

and 138 for the actin assay were performed. These replicates were performed on two ABI 7700 Sequence Detection Units using multiple lots of reagents and multiple operators over a twelve-month period. Tables 3 and 4 show the variability of the $5^{\prime} \mathrm{UTR}$ and actin assays. The variability was calculated by using the standard curve and calculating the value for each individual point along the curve. As would be 
expected, the variability for both assays increased as the amount of analyte decreased. The coefficient of variation (standard deviation divided by mean) showed similar trends in both the 5'UTR and actin assays, with the actin being less variable at the lower levels of quantitation. The actin assay was not regulated by the administration of DNA/lipid complexes (data not shown).

\section{Quantifying Transgene Expression In Vivo}

In vivo transfections with three plasmids containing different cDNAs were used to illustrate the utility of the 5'UTR assay. All three plasmids contained the PGL3 intron in the $5^{\prime}$ UTR region that is targeted in the quantitative RT-PCR assay. Animals were in- jected intravenously with cationic lipid/DNA formulations, and lung tissue was harvested at different times post-injection. Total RNA prepared from the tissues was analyzed for both the target transcript and murine actin. As shown, transcripts from all three expression constructs could be detected (Figure 3, A-C). The data demonstrates that the assay has sufficient sensitivity and specificity to detect time-dependent changes in expression following in vivo transfection.

\section{Comparison to Traditional Northern Blot Using In Vivo Samples}

To further qualify the qRT-PCR technique for use in vivo, traditional northern hybridization techniques were used to quantitate expression levels in a

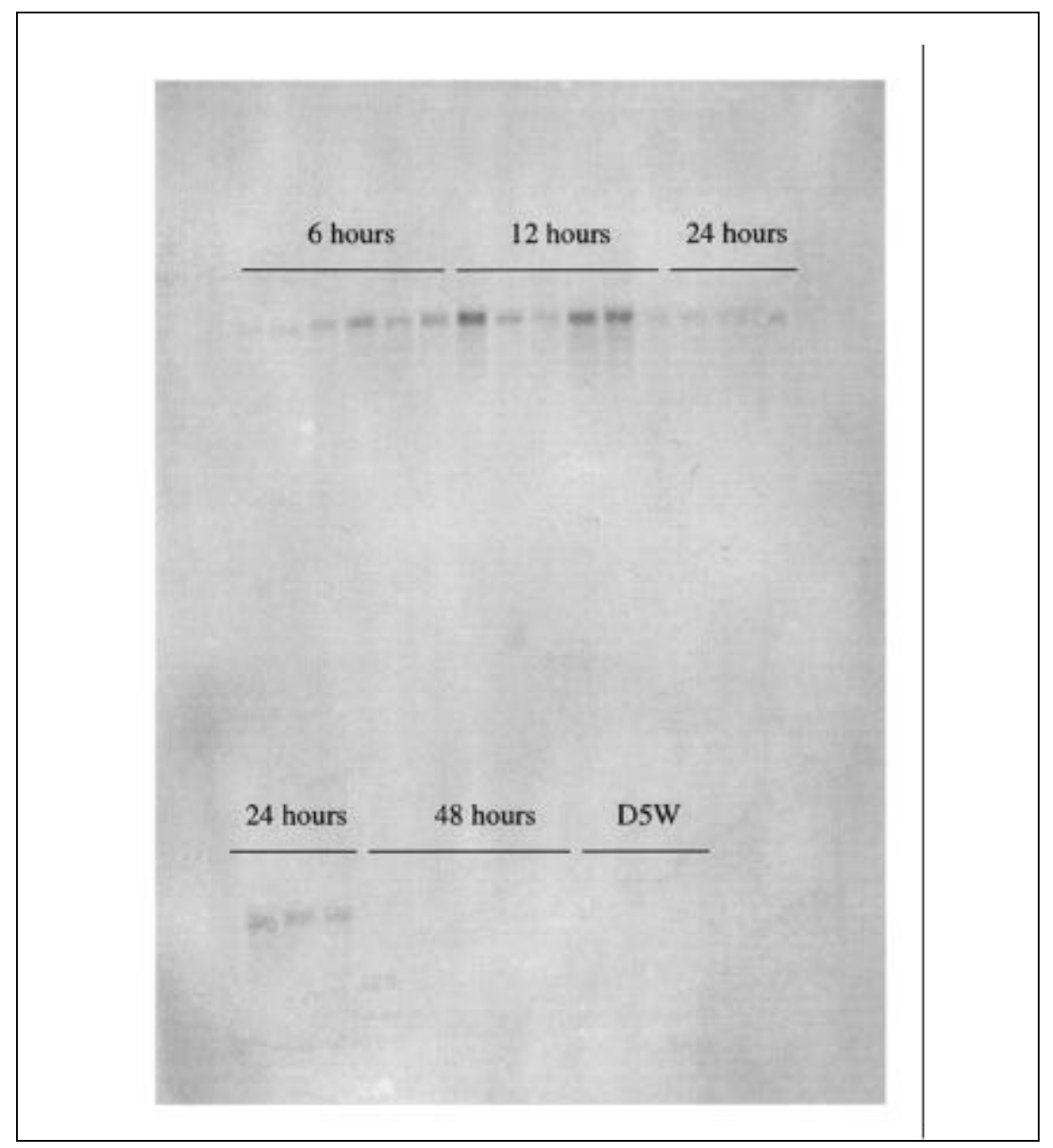

Figure 4. Northern blot to determine transgene expression. One microgram of poly(A)+ RNA from each sample was analyzed. Probe sequences were complimentary to the human G-CSF coding region of the expression vector. 
number of samples and compared with qRT-PCR (Figure 4 and Table 5). The qualitative measurement obtained by northern hybridization confirmed the values obtained by qRT-PCR.

\section{DISCUSSION}

There are few alternatives to quantitatively measure expression of genebased therapeutics in vivo. One option to ensure recognition of only the transgene is to design amplification primers that recognize a combination of the vector and gene of interest (5). A significant amount of time would be required to develop and characterize assays that are specific to each gene of interest. An alternative is to design primers from within the coding region, and assume that the expression of the endogenous gene is constant or nonexistent (3). The disadvantage of this approach is that the administration of cationic lipid/DNA complex might regulate cytokine expression in vivo (2). This may not be an advantage in certain therapeutic applications, such as autoimmunity and inflammation.

We chose to use a synthetic sequence in the $5^{\prime}$ UTR of the expression construct that does not interfere with protein expression or function. This sequence was used to design PCR primers and a probe that can be used with TaqMan methodology to quantitatively measure RNA levels. The region was chosen because it is outside of the cloning regions for the promoter and gene of interest, allowing a single assay to be applicable to any expression construct with the target sequence. The assay evaluates expression without the modification of the coding sequence, and yet retains the ability to distinguish between endogenous and exogenous gene expression. Because this quantitative RT-PCR assay system is designed using a common platform, it eliminates the need for assay development in the evaluation of different gene products or promoters. Furthermore, one assay validation package can be used for multiple regulatory submissions.

To demonstrate that the assay detects levels of expression after in vivo transfection, experiments were conducted to monitor the kinetics of expression of three different transgenes. Changes in expression over time could be monitored with the assay. We have also demonstrated that the assay is consistent with a traditional method of determination of transgene expression, the northern blot.

The use of such a universal assay system would minimize the chance of systematic error that could be an issue in the comparison of expression, using gene-specific assay systems. We believe that assays such as this will assist in the identification and characterization of plasmid delivery systems and their ability to target specific tissues. This assay is currently being used to correlate mRNA expression with preclinical efficacy in multiple animal models.

\section{ACKNOWLEDGMENTS}

The authors wish to thank the Core Technology group at Valentis for pro- viding the DNA and DNA/lipid complexes for the study, as well as Dezz Ropp and Stefan Ambs for critical reading of this manuscript.

\section{REFERENCES}

1.Ferre, F. 1992. Quantitative or semi-quantitative PCR: reality versus myth. PCR Methods Appl. 2:1-9.

2.Freimark, B.D., H.P. Blezinger, V.J. Florack, J.L. Nordstrom, S.D. Long, D.S. Deshpande, S. Norchumson and K.L. Petrak. 1998. Cationic lipids enhance cytokine and cell influx levels in the lung following administration of plasmid: cationic lipid complexes. J. Immunol. 160:4580-4586.

3.Gibson, U.E.M., C.A. Heid and P.M. Williams. 1996. A novel method for real-time quantitative RT-PCR. Genome Res. 6:9951001.

4.Heid, C.A., J. Stevens, K.J. Livak and P.M. Williams. 1996. Real-time quantitative PCR. Genome Res. 6:986-994.

5.Mahato, R.I., K. Anwer, F. Tagliaferri, C. Meaney, P. Leonard, M.S. Wadhwa, M. Logan, M. French and A. Rolland. 1998. Biodistribution and gene expression on lipid/plasmid complexes after systemic administration. Hum. Gene Ther. 9:2083-2099.

6.Raeymaekers, L. 1995. A commentary on the practical applications of competitive PCR. Genome Res. 5:91-94.

7.Sharp, P.A., A.J. Berk and S.M. Berget. 1980. Transcription maps of adenovirus. Methods Enzymol. 65:750-768.

8.Smith, J.G., T. Wedeking, J.H. Vernachio, H. Way and R.W. Niven. 1998. Characterization and in vivo testing of a heterogeneous cationic lipid-DNA formulation. Pharmacol. Res. 15:1356-1363.

9.Southern, E.M. 1975. Detection of specific sequences among DNA fragments separated by gel electrophoresis. J. Mol. Biol. 98:503-517.

10.Thomas, P.S. 1980. Hybridization of denatured RNA and small DNA fragments transferred to nitrocellulose. Proc. Natl. Acad. Sci. USA 77:5201-5205.

Received 24 November 1998; accepted 4 June 1999.

Address correspondence to:

Isabella Pieslak

Valentis, Inc.

863A Mitten Road

Burlingame, CA 94101, USA

Internet: ipieslak@valentris.com 